Journal of Epidemiology and Public Health 2016, 1(3): 182-194

https://doi.org/10.26911/jepublichealth.2016.01.03.05

\title{
The Effect of Self-Efficacy, Family Support, and Socio-Economic Factors on the Quality of Life of Patients with Breast Cancer at Dr. Moewardi Hospital, Surakarta
}

\author{
Lusiatun'), Ambar Mudigdo², Bhisma Murti') \\ ${ }^{1)}$ Masters Program in Public Health, Universitas Sebelas Maret, Surakarta \\ 2)Department of Anatomy and Pathology, Faculty of Medicine, \\ Universitas Sebelas Maret, Surakarta
}

\begin{abstract}
Background: Breast cancer is the highest cancer among women in the world. Patients with breast cancer experience various changes, including physical, psychological and social changes. This changes affect their quality of life. This study aimed to determine the effect of self-efficacy, family support, and socio-economic factors on health-related quality of life of patients with breast cancer.

Subjects and Method: This was an analytic observational study with cross sectional design. The study was conducted at Dr Moewardi Hospital, Surakarta. A total of 63 patients with breast cancer diagnosis were selected for this study by purposive sampling. The dependent variable was healthrelated quality life, consisting of global health status, physical function, role function, emotional function, social function, fatigue, pain, body image, financial hardship, and future perspective. The independent variables were self-efficacy, family support, education, and family income. The data were collected by questionnaire and medical record, and then were analyzed by multiple logistic regression.
\end{abstract}

Results: Average age (and standard deviation) of the breast cancer patients under study was Mean $=50.21 ; \mathrm{SD}=7.67$ years. Average score of quality of life in the global health status dimension was Mean $=73.81 ; \mathrm{SD}=10.97$. Multiple logistic regression analysis showed positive effect of self-efficacy $(\mathrm{OR}=3.45 ; 95 \% \mathrm{CI}=0.98$ to $12.12 ; \mathrm{p}=0.053)$, family support $(\mathrm{OR}=2.67 ; 95 \% \mathrm{CI}=0.84$ to 8.46 ; $\mathrm{p}=0.096)$, education $(\mathrm{OR}=3.99 ; 95 \% \mathrm{CI}=1.15$ to $13.79 ; \mathrm{p}=0.028)$, and family income $(\mathrm{OR}=1.51$; $95 \% \mathrm{CI}=0.43$ to $5.26 ; \mathrm{p}=0.518$ ) on global health status.

Conclusion: Self-efficacy, family support, education, and family income have positive and significant effects on global health status.

Keywords: self-efficacy, family support, social economy, quality of life, breast cancer

\section{Correspondence :}

Lusiatun. Masters Program in Public Health, Universitas Sebelas Maret, Jl. Ir. Sutami 36 A, Surakarta, Central Java. Email: lusiatun12@gmail.com. Mobile: 085743778941

\section{BACKGROUND}

Epidemiology of disease has undergone a shift, that is changes in disease patterns which were initially dominated by infectious diseases, are now more dominated by non-communicable diseases (Ministry of Health, 2013). Non-communicable diseases annually kill around 38 million people and nearly three-quarters of these deaths occur in low and middle-income countries (WHO, 2015). Indonesia is currently experiencing a double burden of disease, besides non-communicable diseases have become a major burden, infectious diseases are still a heavy burden (Ministry of Health, 2015).

Cancer is included in one of the most contagious causes of death after heart disease (WHO, 2015). The 2012 International Agency for Research on Cancer (IARCH) estimates 14.1 million new cases of cancer worldwide, of which about 8 million cases occur in developing countries. Cancer pro- 
blems in Indonesia continue to increase. The report from the Global Burden Cancer (GLOBOCAN) in 2012 estimates that the incidence of cancer in Indonesia is 134 per 100,000 population (Ministry of Health, 2015).

Breast cancer is the highest frequency type of cancer in the world that occurs in women. There are about 1.7 million new cases and an estimated 521,900 deaths from breast cancer occur in 2012 (American Cancer Society, 2015). Based on data from GLOBOCAN (2012), the estimated percentage of new cases in breast cancer is $43.3 \%$ and the percentage of deaths is $12.9 \%$. The estimated incidence of breast cancer in Indonesia is 40 per 100,000 women. This figure is increased compared to year 2002 which only amounted to 26 per 100,000 women (Ministry of Health, 2015).

Cancer or malignant tumors are uncontrolled growth and spread of cells/tissues, continue to grow or increase, and are immortal (unable to die) (Ministry of Health, 2013; American Cancer Society, 2015). Breast cancer is a carcinoma that originates from the ducts or lobules of the breast $(\mathrm{Su}-$ yatno and Pasaribu, 2010).

Less knowledge about breast cancer, is one of the causes of breast cancer cases being handled late. When breast cancer is detected early and has adequate diagnosis and treatment, there will be a greater chance that breast cancer can be cured. If it's too late to detect, curative treatment is often no longer effective. So that an effective approach is with palliative care (reducing pain, spiritual and psychosocial support) to reduce the suffering of patients and their families (WHO, 2015).

Cancer sufferers will experience physical and psychological changes because they have to adjust to new conditions in their lives. Sadness, worry, fear of the future and death are always a problem for can- cer sufferers. In addition, long-lasting treatment has a high effect of pain and worries about medical costs which have an impact on increasingly weak conditions and even depression. The suffering will affect the quality of his life (Prastiwi, 2012). Confidence or self-efficacy affects how a person acts for personal health and about the mind set of health behavior (Palsdottir, 2008 in Endang, 2012). Self-efficacy is very important for patients in seeking drugs to recover or minimize breast cancer cells (Endang, 2012). De Groot (2002) study results in the Ministry of Health (2015) show that cancer affects the psychological condition of patients to experience distress or distress. Some study results also show that the psychological conditions of cancer patients with distress conditions who always get social support turned out to be positively related to reduced depression.

Based on data from Regional Public Hospital DR Moewardi Surakarta in February 2016, data on breast cancer patient visits for 2014 were 9,909 outpatients and 3,583 hospitalized patients. Whereas in 2015 experienced an increase of 13,221 outpatient visits and 4,596 inpatients. The incidence of breast cancer continues to increase every year.

Based on this background the authors were interested in knowing the effect of self-efficacy, family support and socio-economic on the quality of life of breast cancer patients at Dr. Moewardi Hospital.

\section{SUBJECTS AND METHOD}

\section{Study Design}

This was a quantitative study with analytic observational studies with cross sectional design. This study was conducted at Dr. Moewardi Hospital.

\section{Population and Sampling}

A total of 63 breast cancer patients at the Poly Oncology outpatient installation from 
Journal of Epidemiology and Public Health 2016, 1(3): 182-194

https://doi.org/10.26911/jepublichealth.2016.01.03.05

March to May 2016 was selected by purposive sampling.

\section{Study Variables}

The dependent variable was the quality of life of breast cancer patients consisting of global health status, physical function, role function, emotional function, social function, symptoms of fatigue, pain, and financial difficulties. While the independent variables consist of self-efficacy, family support, mother's education level, and family income. Retrieval of data on individual variables required a questionnaire.

\section{Study Instrument}

The retrieval of quality of life data used the questionnaire of The European Organization for Research and Treatment of Cancer
Quality of Life Questionnaire version 3.0 (EORTC QLQ-C30 version 3.0)

\section{Data Analysis}

Data were analyzed using multiple logistic regression analysis.

\begin{tabular}{l}
\hline RESULT \\
\hline 1. Univariate analysis \\
Characteristics of the study subjects were \\
obtained from sociodemographic data (age, \\
education, family income, source of treat- \\
ment costs, and marital status), clinical \\
data (stage of cancer and duration of can- \\
cer) and the quality of life of breast cancer \\
patients based on the results of the EORTC \\
QLQ-C3O.
\end{tabular}

Table 1. Sociodemographic characteristics and clinical data of study subjects

\begin{tabular}{lccc}
\hline \multicolumn{1}{c}{ Subject characteristics } & n (\%) & Mean (SD) & Range \\
\hline Maternal age (year) & $14(22.2)$ & $50.21(7.67)$ & 26 to 73 \\
a. $<45$ & $49(77.8)$ & & \\
b. $\geq 45$ & & & \\
Education level & $33(52.4)$ & & \\
a. Low < High school & $30(47.6)$ & & 600,000 to \\
b. High $\geq$ High school & & & \\
Family income (rupiah) & $38(60.3)$ & $1,512,698$ & \\
a. Low < Regional minimum wage & $25(39.7)$ & $(983,204)$ & \\
b. High $\geq$ Regional minimum wage & & & \\
Marital status & $2(3.2)$ & & \\
a. Single & $53(84.1)$ & & \\
b. Married & $8(12.7)$ & & \\
c. Widow & & & \\
Stage of cancer & $21(33.3)$ & & \\
a. Stage II & $30(47.6)$ & & \\
b. Stage III & $12(19)$ & & \\
c. Stage IV & & & \\
Duration of cancer (months) & $27(42.9)$ & & \\
a. < 2 years (24 months) & $23(36.5)$ & & \\
b. 2-5 years (24-6o months) & $13(20.6)$ & & \\
c. $\geq 5$ years ( $\geq 60$ months) & & & \\
\hline
\end{tabular}

Table 1 showed that the youngest breast cancer patient was 26 years old and the oldest was 73 years old, with the average patient suffering from breast cancer at the age of 50 years. For maternal education level as many as 33 people (52.4\%) were less than high school and 30 people $(47.6 \%)$ we- re educated more or equal to high school. Most of the maternal family income was less than the regional minimum wage which was $60.3 \%$. Meanwhile, regarding the marriage status, as much as $84.1 \%$ were married, and the rest were widowed or unmarried. Based on the cancer stage of breast 
cancer patients, the highest number was in stage III, which was 30 people (47.6\%).

\section{Multivariate analysis}

The multivariate analysis used was a multiple logistic regression model, with a predictor of the life quality of breast cancer patients. Independent variables in this study included self-efficacy, family support, mother's education level and family income.

\section{a. Self-efficacy}

There was a strong positive influence between self-efficacy and global health status and was statistically almost significant. Patients with high self-efficacy improved global health status by as much as 4 times greater than patients with low self-efficacy $(\mathrm{OR}=3.45 ; 95 \% \mathrm{CI}=0.98$ to $12.12 ; \mathrm{p}=0.053)$.

There was a strong positive influence between self-efficacy and physical function and it was statistically close to significant $(\mathrm{OR}=3.09 ; 95 \% \mathrm{CI}=0.96$ to $9.98 ; \mathrm{p}=0.059)$. Regarding the role function, there was a weak positive influence but it was not statistically significant $(\mathrm{OR}=1.46 ; 95 \% \mathrm{CI}=$ 0.44 to $4.82 ; \mathrm{p}=0.534)$. There was a positive influence on emotional function but it was not statistically significant $(\mathrm{OR}=1.93$; $95 \% \mathrm{CI}=0.61$ to 6.01 ). There was a moderate positive effect on social function but was not statistically significant $(\mathrm{OR}=1.65 ; 95 \%$ $\mathrm{CI}=0.51$ to $5.3 ; \mathrm{p}=0.397)$.

There was a negative effect of self-efficacy on fatigue and it was statistically almost significant $(\mathrm{OR}=0.33 ; 95 \% \mathrm{CI}=0.09$ to $1.22 ; \mathrm{p}=0.098$ ). Pain also had an inverse effect, but it was not statistically significant $(\mathrm{OR}=0.43 ; 95 \% \mathrm{CI}=0.13$ to $1.42 ; \mathrm{p}=$ 0.166). There was an inverse effect on financial difficulties and it was statistically significant $(\mathrm{OR}=0.25 ; 95 \% \mathrm{CI}=0.07$ to $0.35 ; \mathrm{p}=0.035)$. Patients with high self-efficacy would reduce fatigue and pain.

\section{b. Family support}

Family support was strongly positive for global health status but it was not statisti- cally significant $(\mathrm{OR}=2.67 ; 95 \% \mathrm{CI}=0.84$ to $8.46 ; \mathrm{p}=0.096)$. Family support had a positive effect on physical function $(\mathrm{OR}=$ $2.84 ; 95 \% \mathrm{CI}=0.89$ to $9.01 ; \mathrm{p}=0.076)$, on role function $(\mathrm{OR}=2.69 ; 95 \% \mathrm{CI}=0.86$ to 8.44; $\mathrm{p}=0.088)$. Customer support had a positive effect on emotional function ( $\mathrm{OR}=$ 1.77; $95 \% \mathrm{CI}=0.58$ to $5.32 ; \mathrm{p}=0.312)$, and on social function $(\mathrm{OR}=3.70 ; 95 \% \mathrm{CI}=1.20$ to $11.43 ; \mathrm{p}=0.023$ ). Family support had negative affect on fatigue and it was statistically significant $(\mathrm{OR}=0.25 ; 95 \% \mathrm{CI}=0.08$ to $0.85 ; \mathrm{p}=0.026)$ and on pain $(\mathrm{OR}=0.29$; 95\% CI= 0.09 to $0.93 ; \mathrm{p}=0.037$ ), and had a positive effect on financial difficulties but it was not statistically significant $(\mathrm{OR}=0.61$; 95\% CI= 0.19 to $1.95 ; \mathrm{p}=0.405$ ).

Family support had a positive influence on body image $(\mathrm{OR}=1.28 ; 95 \% \mathrm{CI}=0.41$ to $4.01 ; \mathrm{p}=0.254$ ) and had a positive influence on the perspective of the future $(\mathrm{OR}=$ 2.74; 95\% CI=0.87 to 8.64; $\mathrm{p}=0.085$.

\section{c. Maternal education level}

Maternal education level had a strong positive effect on global health status and it was statistically significant $(\mathrm{OR}=3.99 ; 95 \% \mathrm{CI}=$ 1.15 to $13.79 ; \mathrm{p}=0.028$ ). The high level of maternal education would increase global health status by 4 times compared to mothers with low education.

Maternal education level had a positive effect on physical function $(\mathrm{OR}=1.22$; $95 \% \mathrm{CI}=0.37$ to $3.99 ; \mathrm{p}=0.741)$, on role function $(\mathrm{OR}=2.47 ; 95 \% \mathrm{CI}=0.78$ to 6.90 ; $\mathrm{p}=0.780$ ), on social functions $(\mathrm{OR}=01.37$; $95 \% \mathrm{CI}=0.44$ to $4.34 ; \mathrm{p}=0.585)$ and on emotional function $(\mathrm{OR}=1.65 ; 95 \% \mathrm{CI}=$ 0.54 to $5.01 ; p=0.377$ ).

Maternal education level had a negative effect on fatigue $\mathrm{OR}=0.21 ; 95 \% \mathrm{CI}=$ 0.06 to $0.78 ; \mathrm{p}=0.020)$, on pain $(\mathrm{OR}=$ $0.88 ; 95 \% \mathrm{CI}=0.27$ to $2.85 ; \mathrm{p}=0.833)$ and on financial difficulties $(\mathrm{OR}=0.37 ; 95 \% \mathrm{CI}=$ 0.11 to $1.24 ; p=0.107)$. 
Journal of Epidemiology and Public Health 2016, 1(3): 182-194

https://doi.org/10.26911/jepublichealth.2016.01.03.05

Table 2. The results of multiple logistic regression analysis on self-efficacy, family support, education level, and family income on the quality of life

\begin{tabular}{|c|c|c|c|c|c|c|c|c|c|}
\hline \multirow{2}{*}{\multicolumn{3}{|c|}{ Dependent Variable }} & \multicolumn{7}{|c|}{ Independent Variable } \\
\hline & & & \multicolumn{2}{|c|}{$\begin{array}{l}\text { Self-efficacy } \\
\text { (high) }\end{array}$} & \multicolumn{2}{|c|}{$\begin{array}{c}\text { Famly support } \\
\text { (strong) }\end{array}$} & \multicolumn{2}{|c|}{$\begin{array}{c}\text { Maternal } \\
\text { education level } \\
\geq \text { Senior High } \\
\text { School } \\
\end{array}$} & $\begin{array}{c}\text { Family income } \\
\geq \text { Regional } \\
\text { minimum } \\
\text { wage }\end{array}$ \\
\hline QLQ-C30 & $\mathbf{R}^{2}$ & $\begin{array}{l}-2 \log \\
\text { Likeli- } \\
\text { hood }\end{array}$ & OR & $\mathbf{p}$ & $\begin{array}{c}\text { OR } \\
95 \% \mathrm{CI})\end{array}$ & $\mathbf{p}$ & CI) & $\mathbf{p}$ & $\begin{array}{c}\text { OR } \\
(95 \% \mathrm{CI})\end{array}$ \\
\hline & & & . & 3 & $\begin{array}{r}2.67 \\
8\end{array}$ & & $\begin{array}{r}3.99 \\
13\end{array}$ & & 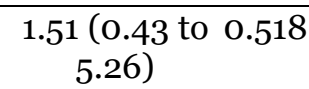 \\
\hline & 20.3 & & $\begin{array}{r}3.09 \\
9\end{array}$ & & $\begin{array}{r}2.84(C \\
9 . C\end{array}$ & & $\begin{array}{r}1.22( \\
3 .\end{array}$ & 741 & 1.36 \\
\hline & 22.8 & & $\begin{array}{r}1.46 \\
4\end{array}$ & 0.534 & $\begin{array}{r}2.69(0 \\
8.4\end{array}$ & & $\begin{array}{r}2.47( \\
7 .\end{array}$ & & $\begin{array}{r}2.48 \\
8\end{array}$ \\
\hline & 13.5 & & $\begin{array}{r}1.93( \\
6\end{array}$ & 0 & $\begin{array}{r}1.77(\mathrm{O} \\
5.3\end{array}$ & & $\begin{array}{r}1.65( \\
5 .\end{array}$ & 0.377 & $\begin{array}{r}2.05 \\
6\end{array}$ \\
\hline & 21.0 & & 1.65 & $\mathrm{o}$ & $\begin{array}{r}3 \cdot 70(1 \\
11 .\end{array}$ & & $\begin{array}{r}1.37(0 \\
4.3\end{array}$ & & $\begin{array}{r}1.94 \\
6\end{array}$ \\
\hline & 32.9 & 67.08 & $\begin{array}{c}0.33 \text { (0.09 to } \\
1.22)\end{array}$ & 8 & $\begin{array}{c}0.25(0.08 \\
0.85)\end{array}$ & 26 & $\begin{array}{c}0.21(0.06 \text { to } \\
0.78)\end{array}$ & & 22 to 0.790 \\
\hline $\mathrm{Pa}$ & & & 0.43 & 0.166 & $\begin{array}{c}0.29(0.09 t \\
0.93)\end{array}$ & & $\begin{array}{r}0.88( \\
2 .\end{array}$ & 833 & $\begin{array}{r}0.45 \\
1 .\end{array}$ \\
\hline $\begin{array}{l}\text { Financial } \\
\text { difficulties }\end{array}$ & 28.9 & 71.93 & $\begin{array}{c}0.25 \text { (0.07 to } \\
0.35)\end{array}$ & 0.035 & $\begin{array}{c}0.61(0.19 \mathrm{t} \\
1.95)\end{array}$ & 405 & $\begin{array}{c}0.37 \text { (o.11 to } \\
1.24)\end{array}$ & 0.107 & $\begin{array}{l}0.27(0.07 \text { to } 0.042 \\
0.96)\end{array}$ \\
\hline
\end{tabular}

\section{d. Family income}

Family income had a positive effect on global health status, but it was not statistically significant $(\mathrm{OR}=1.51 ; 95 \% \mathrm{CI}=0.43$ to 5.26 ; $\mathrm{p}=0.518)$. Family income had a positive effect on physical function $(\mathrm{OR}=1.36$; $95 \%$ $\mathrm{CI}=0.40$ to $4.57 ; \mathrm{p}=0.625$ ), role function $(\mathrm{OR}=2.48 ; 95 \% \mathrm{CI}=0.74$ to $8.23 ; \mathrm{p}=$ 0.137), emotional function $(\mathrm{OR}=2.05 ; 95 \%$ $\mathrm{CI}=0.66$ to $6.38 ; \mathrm{p}=0.217)$, and social function $(\mathrm{OR}=1.94 ; 95 \% \mathrm{CI}=0.59$ to 6.29 ; $\mathrm{p}=0.272)$. Family income had a negative effect on fatique $(\mathrm{OR}=0.83 ; 95 \% \mathrm{CI}=0.22$ to $3.07 ; \mathrm{p}=0.790)$, pain $(\mathrm{OR}=0.45 ; 95 \%$ $\mathrm{CI}=0.13$ to $1.52 ; \mathrm{p}=0.202)$, and financial difficulties $(\mathrm{OR}=0.27 ; 95 \% \mathrm{CI}=0.07$ to 0.96; $\mathrm{p}=0.042)$.

\section{DISCUSSION}

\section{Self-efficacy}

\section{a. The effect of self-efficacy on global health status}

Quality of life on global health status consisted of general health assessment and the general well-being of patients assessment. The results of this study indicated that selfefficacy had a strong positive effect on global health status $(\mathrm{OR}=3.15 ; 95 \% \mathrm{CI}=0.98$ to $10.11 ; p=0.054)$. This was in accordance with the results of the study by Liang et al., (2016) that self-efficacy played an important role in health behavior, which would affect the improvement of health and wellbeing.

According to Bandura's (1994) theory, efficacy is a person's belief in his ability to regulate and do something influential in his life. Self-efficacy helps determine how much effort a person has spent in a behavior, how long they will survive in the face of obstacles and how strong they are in dealing with adverse situations. So that the higher the self-efficacy of breast cancer sufferers, they would try to overcome the problems that occur in themselves through efforts to obtain healing and avoid things that could reduce their health status. 


\section{b. The effect of self-efficacy on QLQ- C3o function scale}

The quality of life on the QLQ-Q30 function scale analyzed in this study included aspects of physical function, role function, emotional function, and social function. The higher the value on this function scale, the better the quality of life.

Self-efficacy in general had a positive influence on the quality of life of breast cancer patients on the QLQ-C30 function scale. The influence was positively strong for the aspect of physical function and statistically close to significant $(\mathrm{OR}=3.09)$. There was a positive and weak influence on the role function but it was statistically insignificant $(\mathrm{OR}=1.46)$. There was a moderate positive influence on emotional function but not statistically significant $(\mathrm{OR}=1.93)$, and there was a positive influence on social function but not statistically significant $(\mathrm{OR}=$ 1.65). This meant that high self-efficacy would have an effect on improving the quality of life on physical function aspects, role function, emotional function and social function. The greater the OR value, the greater the influence.

In accordance with the SCT theory, a person's social and cognitive processes will influence human motivation, emotions and actions (Tarsidi, 2010). Someone who is diagnosed with cancer will experience various kinds of emotional reactions or negative actions, such as withdrawing from the surrounding environment, consuming a sedative drug. Even some patients also refuse to operate, continue chemotherapy and or do not seek treatment, so this can aggravate the situation (Chan and Haber, 2007 in Endang, 2012).

Self-efficacy is very influential in achieving a person's success, so that in this case the role of efficacy is needed. Human success and prosperity can be achieved with a sense of optimism, when in many social re- alities life challenges such as obstacles, misery, setbacks, frustration and injustice must be faced. A high sense of self-efficacy will create resistance to these challenges, so as to be able to do various efforts and exercise self-control (Rini, 2011). Thus patients with high self-efficacy will always try to improve their physical, emotional, role, cognitive and social functions. They will think optimistically about the disease and always try to control themselves to stay strong in dealing with the problem.

\section{c. The effect of efficacy on symptom scale and impact on QLQ-C3O}

Quality of life on the symptom scale and the impact on QLQ-C30 analyzed in this study consisted of symptoms of fatigue, pain and financial difficulties. The greater the value on the symptom scale and this impact, the worse the quality of life.

In this study, self-efficacy in general had the effect of reducing the scale of symptoms and the impact on QLQ-C30 breast cancer patients. Self-efficacy had the effect of reducing the symptoms of fatigue $(\mathrm{OR}=$ o.33), pain symptoms $(\mathrm{OR}=0.43)$, and the effect of reducing the impact of financial difficulties $(\mathrm{OR}=0.25)$. Breast cancer patients with high self-efficacy would reduce symptoms/complaints and the effects of breast cancer, especially on fatigue symptoms, pain symptoms and financial difficulties compared to patients with low self-efficacy. The smaller the OR value, the greater the effect of reducing symptoms and the effects of breast cancer, so that the quality of life was better.

According to Liang et al., (2016) symptom management with self-efficacy in breast cancer patients is an important mechanism for dealing with symptoms of distress that affect the quality of life of breast cancer patients.

A high sense of efficacy will be an effort to solve the problems they face and im- 
Journal of Epidemiology and Public Health 2016, 1(3): 182-194

https://doi.org/10.26911/jepublichealth.2016.01.03.05

prove their quality of life through integrated efforts. High confidence, how much effort is done, and how strong the obstacles encountered will affect the collective success of the effort made (Bandura, 1994). Cancer sufferers will always try to overcome all kinds of symptoms of discomfort due to cancer or the consequences of treatment. With high accuracy, the patient will try to survive with poor conditions.

\section{Family support}

\section{a. The effect of family support on glo-} bal health status

In this study, family support had a moderate positive relationship to the global health status of breast cancer patients, with an $\mathrm{OR}=2.67$. It meant that strong family support increased global health status by 2.67 times higher than patients with weak family support. This was in line with the study conducted by Castro (2013) that all support especially the support of family and friends played an important role in improving aspects of quality of life in general, satisfaction with health, physical, psychological, social and environmental.

Larger social networks are thought to have a better prognosis for patients with breast cancer, but this relationship depends on the quality and burden of family relationships (Kroenke et al., 2013). Bandura's SCT theory model showed that the environment was one model that influenced one's behavior. Family support was one example of an environmental model that had an influence in determining the behavior of breast cancer patients in overcoming their disease which would affect their quality of life. In dealing with the problem, cancer sufferers needed support from the people around them, especially families. Family was one of the reasons they wanted to get well. When there was support from the outside, they would feel cared for and their presence was still needed. So, they would always try to be as active as possible and wanted to always improve their health.

\section{b. The effect of family support on QLQ-C3o function scale}

In general, family support had a positive influence on the quality of life of cancer patients in this study. Family support had a positive effect on physical function $(\mathrm{OR}=$ 2.84), role function $(\mathrm{OR}=2.69)$, emotional function $(\mathrm{OR}=1.77)$, and social function $(\mathrm{OR}=3.70)$. High family support could improve the quality of life on the QLQ-C30 function scale on aspects of physical function, role function, emotional function and social function. According to Krug et al., (2016) families of cancer patients participate in palliative care at home, understanding the dependence/inability of cancer patients and families as service providers for them in their daily needs. Based on the results of his study, it was stated that patients who underwent palliative care by involving their families, their quality of life as a whole increased towards the end of life, even though physical function decreased.

One of the functions of the family is to care/maintain health, maintain the health of family members in order to remain high productivity (Friedman in Prasetyawati, 2011). Thus, the greater the family support will affect the increasing quality of life on the function scale of breast cancer patients.

\section{c. The effect of family support on symptom scale and impact on QLQ- C3o}

Family support had an inverse or negative effect and it was statistically significant on fatigue $(\mathrm{OR}=0.25 ; 95 \% \mathrm{CI}=0.08$ to 0.85 ; $\mathrm{p}=0.026)$ and pain $(\mathrm{OR}=0.29 ; 95 \% \mathrm{CI}=$ 0.09 to $0.93 ; p=0.037$ ), and had a negative effect on financial difficulties but was not statistically significant $(\mathrm{OR}=0.61 ; 95 \% \mathrm{CI}=$ 0.19 to $1.95 ; p=0.405$ ). Strong family support could reduce the scale of symptoms 
and impacts, compared to those who had weak family support.

Northouse et al., (2005) stated that in the treatment of breast cancer patients plus family intervention, significantly reduced feelings of despair and negative feelings compared to those without family intervention. The effect of this intervention was especially evident in the first three months.

Individual health problems are a component of the maintenance system of the individuals concerned, individuals as part of the family and society, which includes biomedical, psychological aspects, aspects of knowledge, attitudes and behavior, social and environmental aspects (Prasetyawati, 2009). The role of the family is needed in an effort to help reduce the symptoms that arise due to cancer and or the effects of cancer therapy.

\section{Maternal education level}

\section{a. The effect of maternal education level on global health status}

In this study the maternal education level had a strong positive influence on global health status and it was statistically significant $(\mathrm{OR}=3.99)$, this meant that the level of maternal education $\geq$ Senior High School could improve global health status by 4 times. Statistically, this relationship was significant because the coincidence role was very small, ie less than 28 of the 1,000 findings available $(\mathrm{p}=0.028)$.

Based on the results of study by Pradono and Sulistyowati (2013), health status was positively and significantly related to knowledge (51.6\%), healthy living behavior (48.2\%) and education level (47.1\%). There was a positive effect of the education length (years) on consistent health. The length of education could develop an effective life capacity which would ultimately affect a person's health, including part-time work, could run a good job, improve welfare, economy, self-control, greater social support, and a healthy lifestyle (Pradono and Sulistyowati, 2013).

\section{b. The effect of maternal education level on QLQ-C3o function scale}

In general, the level of education had a positive influence on the quality of life on the QLQ-C30 function scale in this study. The maternal education level had a positive influence on physical function $(\mathrm{OR}=1.22)$, role function $(\mathrm{OR}=2.47)$, social function $(\mathrm{OR}=01.37)$ and emotional function $(\mathrm{OR}=$ 1.65). In this case, it showed that the level of maternal education could improve the quality of life of breast cancer patients in aspects of physical function, role function, emotional function and social function. The greater the OR value, the greater the influence of the relationship.

The quality of life of cancer patients is influenced by an individual's understanding of the disease so that someone knows how to maintain health. The higher the education, the greater the exposure to information about cancer, compared to those of lower education (Pratiwi, 2012; Oemiati et al., 2011). Thus, the higher education will affect a person's health behavior, which will have implications for improving a person's quality of life.

\section{c. The effect of maternal education level on QLQ-C30 symptom scale}

Maternal education level had a negative effect on fatigue $(\mathrm{OR}=0.21)$, pain $(\mathrm{OR}=0.88)$ and financial difficulties $(\mathrm{OR}=0.37)$. This meant that the level of maternal education could reduce the symptom scale on fatigue, pain and financial difficulties.

The quality of life of breast cancer patients is also influenced by socio-demographic factors including age, education level, occupation and marital status (Chistina, 2011). Higher education teaches people to think more logically and rationally, can see an issue from various sides so that they can analyze and solve a problem 
better. Higher education improves cognitive skills needed to be able to continue learning outside of school (Laflamme, 2004 in Pradono and Setyowati, 2013). A higher level of knowledge will affect the mother in addressing the existing problems, especially facing fatigue, nausea, vomiting and pain.

\section{Family income}

\section{a. The effect of family income on glo- bal health status}

The amount of family income had a positive influence on the global health status of breast cancer patients, with a value $(\mathrm{OR}=1.51)$, which meant that family income above the regional minimum wage could increase health status by 1.51 times.

Increasing economic status, the need for health services will also increase. Exposure to information about cancer for middle and upper economic groups will be greater than that of the middle to lower economic groups (Oemiati et al, 2011). In addition to understanding the disease, the cost of treatment is a special concern for cancer patients, so it will affect the quality of life of cancer patients (Prastiwi, 2012). According to Budiman et al (2013) socioeconomic factors play a role in patient treatment compliance. The lower the socio-economic status of a person, the more disobedient for treatment. In his study, there is a significant relationship between family income and patient treatment compliance.

Compliance with treatment will affect the health status of patients. Patients who regularly take medication will have better health status compared to non-routine ones.

\section{b. The effect of family income on QLQ-C3o function scale}

The amount of family income had a positive effect on physical function $(\mathrm{OR}=1.36)$, role function $(\mathrm{OR}=2.48)$, emotional function $(\mathrm{OR}=2.05)$, and social function $(\mathrm{OR}=1.94)$.
Socio-economic conditions in general are related to various health problems faced. A good socio-economy will affect a person's awareness, willingness and ability to improve their health. Economic factors, one of which is income, is the main requirement to be able to enjoy health care services in an effort to improve one's health. With this effect, the function scale in breast cancer patients will be increased by regular treatment or coronation, so that the quality of life becomes good.

\section{c. The effect of family income on QLQ-C30 symptom scale}

The amount of family income had the effect of reducing the QLQ-C30 symptom scale on symptoms of fatigue $(\mathrm{OR}=0.83)$, pain $(\mathrm{OR}=0.45)$ and to financial difficulties $(\mathrm{OR}=0.27)$. If symptoms decreased, the quality of life would get better, and vice versa.

Cancer is the main cause of death in the world, with a problem of considerable economic burden. The large impact on costs can be seen from the costs of primary care (including home care), outpatient care in hospitals and hospitalization in hospitals such as medicines, oncological care, radiation therapy, imaging diagnosis, and laboratory costs. Kovacevia et al., (2015).

\section{REFERENCE}

American Cancer Society (2015). Breast cancer facts \& figures 2015-2016. Atlanta: American Cancer Society, Inc

American Cancer Society. (2015). Global cancer facts \& figures, 3rd Edition. Atlanta: American Cancer Society.

Bandura A. (1994). Self-Efficacy in V.S. Ramachaudran (Ed.). Encyclopedia of Human Behavior.4: 71-81. New York: Academic Press.

Budiman A, Khambri D, Bachtiar H (2013). Faktor yang mempengaruhi kepatuhan berobat pasien yang diterapi dengan Tamoxifen setelah operasi 
kanker payudara. Jurnal Kesehatan Andalas. 2(1).

Castro M (2013). Quality of life in female breast cancer survivor in Panama. Graduate Theses and Dissertassions. University of Shouth Florida. Retrieved from http://scholarcommons.usf.edu/etd/4651.

Chistina EF (2011). Kualitas hidup penderita kanker payudara stadium awal yang mendapat kemoterapi ajuvan berbasis antrasiklin. Yogyakarta: Universitas Gadjah Mada. Retrivied from http://etd.repository.ugm.ac.id.

February 2016.

Endang S (2012). Hubungan antara efikasi diri dengan perilaku mencari pengobatan pada penderita kanker payudara di RSUD Ibnu Sina Gresik. Jurnal Psikologi Klinis dan Kesehatan Mental 1 (102). Surabaya: Universitas Airlangga.

Kovacevia A, Dragojevic-Simic V, Rancic N, Jurisevic M, Gutzwiller FS,MatterWalstra K, Jakovljevic M (2015). Endof-life cost of medical care for advanced stage cancer patiens. US National Library of Medicine National Institutes of Health, 72(4): 334-41.

Kroenke CH, Quesenberry C, Kwan ML, Sweeney C, Castillo A, Caan BJ (2013). Social networks, social support and burden in relationships and mortality after breast cancer diagnosis in the life after breast cancer epidemiology (LACE) study. National Institut of Health Public Acces, Breast Cancer Res Treat. 137(1): 261-271

Krug K, Miksch A, Peters-Klimm F, Engeser P, Szecsenyi J (2016). Correlation between patient quality of life in paliative in care and burden of their family caregivers: A perspective observational cohort study. US National Li- brary of Medicine National Institute of Health.

Liang SY, Chao TC, Tseng LM, Tsay SL, Lin $\mathrm{KC}$, Tung $\mathrm{HH}$ (2016). Symptommanagement self-efficacy mediated effects of symptom distress on the quality of life among taiwanese oncology outpatients with breast cancer. US National Library of Medicine National Institute of Health, 39(1):67-73.

Liansyah TM. (2014). Hubungan antara efikasi diri dan dukungan keluarga dengan kualitas hidup pasien asma. Surakarta: Universitas Sebelas Maret.

Ministry of Health (2013). Draft Pedoman Surveilans Penyakit Tidak Menular (12 Desember 2013). Jakarta: Kementerian Kesehatan RI, Direktorat Jenderal Pengendalian Penyakit dan Penyehatan Lingkungan, Direktorat Pengendalian Penyakit Tidak Menular.

Ministry of Health (2013). Riset Kesehatan Dasar Riskesdas 2013. Jakarta: Badan Litbangkes Kementerian Kesehatan RI

Ministry of Health (2015). Infodatin informasi dan data kementerian kesehatan RI. Jakarta Selatan.

Ministry of Health (2015). Rencana strategis kementerian kesehatan tahun 2015-2019. Jakarta: Kementerian Kesehatan RI.

Ministry of Health 2015. Situasi Penyakit Kanker. Buletin Jendela Data dan Informasi Kesehatan,1:1-11. ISSN 2088270X. Jakarta: Pusat Data dan Informasi Kementerian Kesehatan RI.

Murti B (2013). Desain dan ukuran sampel untuk penelitian kuantitatif dan kualitatif di bidang kesehatan. Yogyakarta: Gadjah Mada University Press.

Northouse L, Kershaw T, Mood D, Schafenacker A (2005). Effects of a family intervention on the quality of life of 
Journal of Epidemiology and Public Health 2016, 1(3): 182-194

https://doi.org/10.26911/jepublichealth.2016.01.03.05

women with recurrent breast cancer and their family caregiver. US National Library of Medicine National Institutes of Health, 14(6): 478-91.

Oemiati R, Rahajeng E, Kristanto AY (2007). Prevalensi tumor dan beberapa faktor yang mempengaruhinya di Indonesia. Buletin Penelitian Kesehatan 39(4): 190-204.

Pradono J, Sulistyowati N (2013). Hubungan antara tingkat pendidikan, pengetahuan tentang kesehatan lingkungan, perilaku hidup sehat dengan status kesehatan. Jakarta: Pusat Teknologi Intervensi Kesehatan Masyarakat, Badan Litbang Kesehatan, Kementerian Kesehatan RI.

Prasetyawati AE (2011). Ilmu kesehatan masyarakat untuk kebidanan holistik (Integrasi community oriented ke family oriented). Yogyakarta: Nuha Medika.

Prastiwi TF (2012). Kualitas hidup penderita kanker. Retrivied from http://journal.Unnes.ac.id/sju/index.php/dcp/article/view/2630.1(1).
Rini IS (2011). Hubungan antara efikasi diri dengan kualitas hidup pasien penyakit paru obstruktif kronis dalam konteks asuhan keperawatan di RS Paru Batu dan RSU Dr. Saiful Anwar Malang Jawa Timur. Jakarta: Universitas Indonesia.

Suyatno, Pasaribu ET (2010). Bedah onkologi diagnosis dan terapi. Jakarta: CV Sagung Seto.

Tarsidi D (2010). Teori kognitif sosial Albert Bandura. Jakarta: Universitas Pendidikan Indonesia.

WHO (1996). WHOQOL-BREF Introduction, administration, scoring and generic version of assessment. Geneva: WHO

WHO (2014). Breast cancer awareness month in October. Retrvied from www.who.int/cancer/events/breast_cancer_month/en. January 2016.

WHO (2015). Noncommunicable Diseases. Retrivied from http://www.who.int/mediacentre/factsheets/fs355/en. December 2016. 